\title{
The role of the librarian in developing leadership capabilities in staff
}

\author{
Notes to accompany presentation \\ Professor Michael Hough AM RFD ED \\ 14 Arvenis Cr., BALGOWNIE NSW 2519 Email:- mhough5@ gmail.com
}

\begin{abstract}
This session will focus on the dilemmas and challenges of providing effective leadership skills for modern schools with digital information and communication technology (ICT) capabilities. It will review the selected challenges of engaging different generations of staff in ICT based learning and recommend strategies for effective leadership of ICT based schools. It will particularly focus on the issues of how a librarian and a library can assist to provide relevance and appropriateness of ICT based proposals and programs, and suggest ways to implement leadership policies which enable senior staff to remain accountable whilst all the changes enabled by ICT based learning are occurring within a school.
\end{abstract}

\section{Introduction}

This paper expands the ideas of the keynote address by focussing on the dilemmas of school leaders and staff in providing effective ICT based education, and suggest some action strategies for librarians to use the school iCentre for effective staff development and support of ICT based learning and activities.

\section{The challenges of leadership and ICT based schools}

This seminar essentially takes the view that research based findings are an effective basis for developing improvements in schooling practices including their libraries. With the move to what has been called a "Transparent Democracy", (Hough, 2010) the emergence of much greater official scrutiny, e.g. the mySchool website data, plus unofficial comment and scrutiny, e.g. Wikileaks and Facebook type websites, all combine to mean that schools and their libraries are under much greater scrutiny as to their actions, and therefore need to justify their practices in much more deliberate and open ways.

Accordingly, the remainder of this seminar takes an 'evidence based' approach in providing advice to librarians as to ways of improving their contributions to, and influence on, a modern school community.

What is it that creates an effective school?

Horin (2008, p.33) notes that

A plethora of recent studies have examined the world's successful school systems and all reach the same conclusion: first class teachers are the drivers of school improvement, not constant testing and league tables.

This quote highlights much of the current debate in education in Australia at the moment as to the best ways to improve schools, with the current Federal Government committed to the U.S.A. based systems of investing in systems of pupil achievement, testing and school league tables. The rapid emergence of the mySchool website and the planned myUniversity website are concrete evidence of this public policy commitment.

However, the McKinsey Report (2007), the O.E.C.D. (2007) study on Improving School Leadership and recent work by Caldwell and Harris (2007), all refute this approach and argue for developing high quality teachers as a key to successful schools. O'Keefe (2008, p.20) also refuted the "league table" reporting approach and supports the views of Caldwell and others that investing in teachers is the key to long-term school effectiveness.

Gurr (2008b, pp. 7-10) also reviewed the series of studies by Leithwood and colleagues on school effectiveness, the first of which was reported by Leithwood and Reihl in 2004. Gurr summarised nine policies and practices that promote student learning. Importantly, none of these improvement policies

(C) 2010 IASL, SLAQ and therein by the authors. Diversity Challenge Resilience: School Libraries in Action Proceedings of the $12^{\text {th }}$ Biennial School Library Association of Queensland, the $39^{\text {th }}$ International Association of School Librarianship Annual Conference incorporating the $14^{\text {th }}$ International Forum on Research in School Librarianship, Brisbane QLD Australia, 27 September - 1 October 2010. 
involved the use of external testing and evaluation by league tables. For a more detailed development of this concept see Hough $(2009,256)$.

Hough $(2009,256)$ "An important conclusion to be drawn from all of these findings for school leaders is that if they wish to use ICT more effectively in promoting school effectiveness, then they need to evaluate any ICT based proposals against the criterion of whether it assists the identified school success factors, the paramount one being the development of higher quality teachers." More specifically, (Hough, 2009, 249) "the research on effective school leadership does not identify ICT as a major direct factor in the effective leadership of schools". One way of summarising this set of findings is that ICT create important transformational pressures that have strong impacts on schools, but ICT are not, as yet, research proven as direct factors in themselves.

However, what is clear is that community use of ICT based systems to scrutinise the performance of schools is going to increase, and school teachers, librarians and principals are going to get much more accustomed to the idea that they are under more constant official and unofficial comment and scrutiny.

\section{The needs of teachers in the ICT environment}

In the keynote address conference paper, Table 1 provided an overview summary of how many features evolve and change across different societal eras.

The comparisons in Table 1 illustrate the dilemmas, pressures and problem(s) facing many older teachers (and many principals) in that many were teacher trained in non-ICT based learning and teaching methodologies, delivered by teacher training institutions established to produce teachers for quite a different society and employment context. [A more detailed expansion of these ideas is presented in a summary format in Hough (2008, p.20.]

Black (2008, p. 32) reviewed the recent Australian research on teachers' use of technology across three Australian education sectors. He noted that

Technology is still an 'innovation' rather than a mainstream activity; the most important additional investment needs to be in teachers- to provide the support and professional learning that enables teachers to embed technology into their practices .... Time to learn is the greatest barrier.

The argument here is that principals and executives of schools need to incorporate into their educational leadership thinking the deep understandings that derive from accepting that a major task in developing effective ICT based schools is to assist (many) teachers to successfully adapt to change by developing in them new mindsets and techniques in which they were not initially trained.

Failure to recognise and react professionally (and empathetically) to these staff development challenges can result in increasingly irrelevant schooling practices being defended by teachers who do not regard ICT based learning systems as a positive development / opportunity, and in fact, may see them as a threat.

An attempt to suggest strategies to deal with this situation is provided by sources such as:

1) Zagami \& Finger (2010) who review the following influences and how to implement them:

- Paradigm changing curriculum tools (pp203-204)

- Transforming social networks to learning networks (pp 204-205)

- Teaching and parenting in a 'new' world (pp 205-206)

- Roles for the professional educator (pp208-210).

2) Finger \& Jamieson-Proctor (2010) review a particular approach based on the dynamic and interactive TPCK relationship - Technology, Pedagogy, Content, Knowledge. They identify the five ISTE, (2008) national education technology standards as:-

* Facilitate and inspire student learning and creativity

* Design and develop digital age learning experiences and assessments

* Model digital age work and learning

* Promote and model digital citizenship and responsibility

* Engage in professional growth and leadership (see pp216-217)

(c) 2010 IASL, SLAQ and therein by the authors. Diversity Challenge Resilience: School Libraries in Action Proceedings of the $12^{\text {th }}$ Biennial School Library Association of Queensland, the $39^{\text {th }}$ International Association of School Librarianship Annual Conference incorporating the $14^{\text {th }}$ International Forum on Research in School Librarianship, Brisbane QLD Australia, 27 September - 1 October 2010. 
Finger \& Jamieson-Proctor (20101, Table 14.1. 220-221) provide a detailed conceptualisation of stages of teacher development against school features and redesigned working conditions. They also suggest (2010, 224-225) a redesign of teachers' working conditions based on the following requirements:

- Redesign professional development

- Engage parents and the community

- Exploit digital technologies for redesigning teachers' roles

- Redesign learning spaces

It is clear that the school librarian and the school iCentre (these concepts were developed in detail in the initial keynote address) can be actively involved in supporting or providing a number of these changes. The remainder of this paper together with the active presentation, will provide suggestions for active strategies and approaches to achieve these roles.

Suggestions for librarians and iCentres in support

This seminar paper will provide suggested approaches for a range of needs, commencing with staff development of teachers

\section{The iCentre in support of staff - A typology of staff development}

A useful approach for judging which aspects of staff development should receive priority can be based on a useful conceptualisation first introduced into the literature by Joyce $(1996 ; 1997)$ which can be summarised as

\begin{tabular}{|c|c|c|c|c|}
\hline JOB IMBEDDED & JOB RELATED & $\begin{array}{c}\text { EMPLOYMENT } \\
\text { SYSTEM } \\
\text { RELATED }\end{array}$ & CAREER \\
RELATED & SELF DIRECTED \\
\hline $\begin{array}{c}\text { S.D. Directed at } \\
\text { immediate job } \\
\text { needs }\end{array}$ & $\begin{array}{c}\text { S.D. Directed at } \\
\text { job context needs }\end{array}$ & $\begin{array}{c}\text { S.D. Directed at } \\
\text { employment }\end{array}$ & $\begin{array}{c}\text { S.D. Directed at } \\
\text { career }\end{array}$ & $\begin{array}{c}\text { S.D. Directed at } \\
\text { personal interests } \\
\text { and needs }\end{array}$ \\
$\begin{array}{c}\text { e.g. Classroom } \\
\text { focus }\end{array}$ & $\begin{array}{c}\text { e.g. School/ Year/ } \\
\text { Dept. focus }\end{array}$ & $\begin{array}{c}\text { e.g. Success in } \\
\text { school system }\end{array}$ & $\begin{array}{c}\text { e.g. As a teacher / } \\
\text { as an administrator }\end{array}$ & $\begin{array}{c}\text { e.g. not career } \\
\text { relevant in a } \\
\text { narrow sense }\end{array}$ \\
\hline
\end{tabular}

In analysing which particular staff development (s.d.) aspects are needed, it is clear that developmental considerations such as stages of a teaching career/ career interests/ personal competencies with ICT and so on, will affect the way the above typology could be used.

Essentially, the ICT based needs of teachers and leaders are an important subset of issues to be evaluated using this more generic framework. Obvious uses of an iCentre are:-

- To be the data repository for s.d. needs (identifying, tracking and updating profiles for example)as well as the planned location for the offering of any formal training and development.

- To be the technological hub of the staff / student intranet based learning system on which much of the staff development and student learning should occur

Finger and Proctor (2010, 215-228) provide an excellent review of the needs of teachers for ICT based staff development, with an excellent summary table of developmental needs (Table $14.1 \mathrm{pp}$ 220-221).

\section{General literacy support}

It is useful to remind us all of the actual levels of Australian literacy and support in the Australian community from which our teachers and students are coming. For example (Chalke, 2010) summarised the most recent ABS Adult Literacy and Lifeskills Survey (based on data collected in 2006 but published in 2008) as:-

- Prose literacy (46\% of respondents were below satisfactory (and 26\% of University graduates are below satisfactory)

- Document literacy (47\% of respondents below satisfactory)

(C) 2010 IASL, SLAQ and therein by the authors. Diversity Challenge Resilience: School Libraries in Action Proceedings of the $12^{\text {th }}$ Biennial School Library Association of Queensland, the $39^{\text {th }}$ International Association of School Librarianship Annual Conference incorporating the $14^{\text {th }}$ International Forum on Research in School Librarianship, Brisbane QLD Australia, 27 September - 1 October 2010 . 
- Numeracy literacy (53\% of respondents below satisfactory)

- Problem solving literacy (70\% are below satisfactory)

- Health literacy (60\% are below satisfactory)

It is clear that iCentres have much to contribute to parents, students and teachers in raising the literacy levels of all Australians.

As a 'flow on' from this general data, Rowlands and Nicholas (2008 cited in Lee and Finger 2010, 145-146) summarised the information behaviour of young people as (the following is a paraphrase of the results):

- The information literacy of young people has not improved with their greater access to technology.

- Young people have unsophisticated 'mental maps' of what the Internet is and do not appreciate that it is a collection of networked resources from different providers.

- Many young people do not find library sponsored resources intuitive and therefore prefer to use Google or Yahoo instead.

- As a result a search engine becomes their primary 'brand' that they associate with the Internetand they tend to adopt the tools their friends use.

- The speed of young people's web searching means they have little time for evaluating for relevance, accuracy, or authority, of the obtained information.

- They move rapidly from source to source and spend little time reading or digesting the information, and have difficulty making relevant judgements about the pages they retrieve.

- Observations show that boys scan differently to girls, and that young people scan online pages very quickly (boys rely more on hyperlinks).

- Young people have a poor understanding of their information needs, and therefore have difficulty in developing effective search strategies.

- They make very little use of advanced search facilities, and assume that search engines 'understand' their queries.

- If they obtain many search hits, young people find it difficult to assess the relevance of the materials presented and tend to save or print with little more than a glance at the materials.

Surely this is a most productive starting list for librarians and iCentres to work with both teachers and students to improve the many deficiencies made obvious / inherent in the above summary.

Some typical Australian change pressures / reactions - (Opportunities for iCentres?)

Watson (2008) examined current trends and selected the following as current influences on Australian Society:

- Eco-exhaustion - Tired of eco pressures but acceptance of environmentally authentic people and products.

- Conscious capitalism - Business must incorporate moral and ethical issues and profit must be balanced with lifestyles happiness and harmony.

- Resurgence in individualised hobbies and making things - Emergence of analogue products and personal hobbies especially ones that can benefit the community / disadvantaged **.

- Robotics - Rapid increase in computing power means practical usage of robots is now feasible and will rapidly occur in jobs and households **.

- Rise of industrial provenance - Global communications mean that history of production and life history of products will become very important **.

- Use of Data visualisation - The use of maps / A-V and computer power to assist the rapid processing and bringing meaning to masses of data-a visual culture emerging. ** This will be closely related to:-

- Data mining - Extracting useful and critical information from masses of data. Ranging from national security through to retail and commercial applications **.

- Restoring rhythm and balance to lifestyle - As the world economy speeds up, it will be balanced by things that 'slow down', e.g. slow food / retro fashions / work encouraging disconnected activities. An earlier version was seeing global whole systems, e.g. the Gaia hypothesis of world interconnectivity **

(C) 2010 IASL, SLAQ and therein by the authors. Diversity Challenge Resilience: School Libraries in Action Proceedings of the $12^{\text {th }}$ Biennial School Library Association of Queensland, the $39^{\text {th }}$ International Association of School Librarianship Annual Conference incorporating the $14^{\text {th }}$ International Forum on Research in School Librarianship, Brisbane QLD Australia, 27 September - 1 October 2010. 
- Intimacy industries - Creating space and circles for intimacy and contact beyond online communicationencouraging personal and small group experiences **.

- Fantasy and escape lifestyles - For example, use of sabbaticals; gated communities, second home in rural areas; 'avatars' and role playing. **

( Note: The trends marked with a ** seem to have a major opportunity for engagement by the school community at an iCentre, or using the resources provided through an iCentre)

Leadership support

- A very useful Australian derived conceptualisation of leadership is based on the Cacciope (2004) adaptation of Situational Leadership - where different leadership styles and practices are used to achieve different outcomes. There is a fuller treatment in Hough $(2009,257-258)$ and a visual summary is now provided in a series of tables which summarise important leadership guidelines:Leadership guideline 1

Integral leadership is the ability to develop people and teams to achieve a worthwhile vision and goals for an organisation.

(Comment:-The effective use of ICT based technologies by principals should be assessed by this overall success factor)

Leadership guideline 2

Effective integral leadership requirements need to be supported by appropriate ICT - A selection of the support requirements of ICT. In supporting effective leadership of schools is illustrated by the contents of the following three tables.

Table 1

ICT support of different leadership outcomes

\begin{tabular}{|c|c|c|c|}
\hline $\begin{array}{c}\frac{\text { MAIN }}{\text { OUTCOME }} \\
\frac{\text { QUADRANT OF }}{\text { CONCERN) }}\end{array}$ & $\frac{\text { BASIS OF }}{\text { APPROACH }}$ & $\begin{array}{l}\frac{\text { APPROPRIATE }}{\text { ORGANISAT'L }} \\
\frac{\text { RESPONSES \& }}{\underline{\text { ISSUES }}}\end{array}$ & $\begin{array}{l}\frac{\text { MAJOR USES }}{\underline{\text { OF ICT }}} \\
\text { (i.e. Selecting and } \\
\text { Using ICT to:-) }\end{array}$ \\
\hline $\begin{array}{l}\text { Q1 } \\
\text { COMMUNITY } \\
\text { AND CULTURE } \\
\text { CONCERNS }\end{array}$ & $\begin{array}{l}\text { SPIRIT } \\
\text { (VALUES) }\end{array}$ & $\begin{array}{l}\text { VISION } \\
\text { INNOVATION } \\
\text { CULTURAL } \\
\text { CHANGE }\end{array}$ & $\begin{array}{l}\text { Provide Inclusive } \\
\text { and 24/7 Ways of } \\
\text { Developing, } \\
\text { Disseminating } \\
\text { and Sharing } \\
\text { These Ideas For } \\
\text { The School and } \\
\text { its Community }\end{array}$ \\
\hline $\begin{array}{l}\text { Q2 } \\
\text { PEOPLE WELL } \\
\text { BEING } \\
\text { CONCERNS }\end{array}$ & $\begin{array}{l}\text { HEART } \\
\text { (FEELINGS) }\end{array}$ & $\begin{array}{l}\text { PEOPLE AND } \\
\text { TEAM SKILLS } \\
\text { LIVE THE } \\
\text { VALUES }\end{array}$ & $\begin{array}{l}\text { Facilitate } \\
\text { Dialogue; Share } \\
\text { Wins and Losses; } \\
\text { Develop and } \\
\text { Practise } \\
\text { Electronic } \\
\text { Learning } \\
\text { Communities }\end{array}$ \\
\hline $\begin{array}{l}\text { Q3 } \\
\text { EFFICIENCY } \\
\text { CONCERNS }\end{array}$ & $\begin{array}{l}\text { HANDS } \\
\text { (SKILLS) }\end{array}$ & $\begin{array}{l}\text { PERFORMANCE } \\
\text { MANAGEMENT } \\
\text { RESOURCE } \\
\text { MANAGEMENT }\end{array}$ & $\begin{array}{l}\text { Track and share } \\
\text { performance on } \\
\text { agreed learning } \\
\text { processes and } \\
\text { outcomes } \\
\text { Create efficient }\end{array}$ \\
\hline
\end{tabular}

(C) 2010 IASL, SLAQ and therein by the authors. Diversity Challenge Resilience: School Libraries in Action Proceedings of the $12^{\text {th }}$ Biennial School Library Association of Queensland, the $39^{\text {th }}$ International Association of School Librarianship Annual Conference incorporating the $14^{\text {th }}$ International Forum on Research in School Librarianship, Brisbane QLD Australia, 27 September - 1 October 2010 . 


\begin{tabular}{|l|l|l|l|}
\hline & & $\begin{array}{l}\text { systems and } \\
\text { release humans } \\
\text { for higher order } \\
\text { learning tasks }\end{array}$ \\
\hline $\begin{array}{l}\text { Q4 } \\
\text { CONCETIVENESS }\end{array}$ & $\begin{array}{l}\text { HEAD } \\
\text { (LOGIC) }\end{array}$ & $\begin{array}{l}\text { GOVERNANCE } \\
\text { STRATEGIC } \\
\text { GOALS } \\
\text { BUSINESS } \\
\text { SYSTEMS }\end{array}$ & $\begin{array}{l}\text { Effective ways of } \\
\text { developing and } \\
\text { sharing vision, } \\
\text { goals and } \\
\text { objectives in } \text { e - } \\
\text { learning } \\
\text { communities } \\
\text { Effective systems } \\
\text { for supporting the } \\
\text { business of } \\
\text { learning }\end{array}$ \\
\hline
\end{tabular}

Table 2

ICT support of difference leadership roles

\begin{tabular}{|c|c|c|c|}
\hline$\frac{\text { MAIN OUTCOME }}{\frac{\text { QUADRANT OF }}{\underline{\text { CONCERN })}}}$ & $\begin{array}{l}\frac{\text { SITUATIONAL }}{\text { LEADERSHIP }} \\
\underline{\text { TYPE }} \\
\underline{\text { REQUIRED }}\end{array}$ & $\begin{array}{l}\frac{\begin{array}{c}\text { APPROPRIATE } \\
\text { LEADERSHIP }\end{array}}{\text { ROLES TO ADOPT }} \\
\frac{\text { / DEVELOP }}{\text { (I)=INTERNAL }} \\
\frac{(\text { E)=EXTERNAL }}{\text { FOCUS }}\end{array}$ & $\begin{array}{l}\text { MAJOR USES } \\
\text { OF ICT } \\
\text { (ie Selecting } \\
\text { and Using ICT } \\
\text { to provide or } \\
\text { support:-) }\end{array}$ \\
\hline $\begin{array}{l}\text { Q1 } \\
\text { COMMUNITY } \\
\text { AND CULTURE } \\
\text { CONCERNS }\end{array}$ & $\begin{array}{l}\text { VISIONARY } \\
\text { LEADERSHIP }\end{array}$ & $\begin{array}{l}\text { VISIONARY (E) } \\
\text { FACILITATOR (I) }\end{array}$ & $\begin{array}{l}\text { Effective use of } \\
\text { websites and e- } \\
\text { communications } \\
\text { to inspire, } \\
\text { share, celebrate, } \\
\text { give feedback }\end{array}$ \\
\hline $\begin{array}{l}\text { Q2 PEOPLE } \\
\text { WELL BEING } \\
\text { CONCERNS }\end{array}$ & $\begin{array}{l}\text { PEOPLE } \\
\text { LEADERSHIP }\end{array}$ & $\begin{array}{l}\text { COACH (I) } \\
\text { STEWARD (E) }\end{array}$ & $\begin{array}{l}\text { Effective use of } \\
\text { ICT to establish } \\
\text { goals, coach, } \\
\text { mentor and give } \\
\text { feedback }\end{array}$ \\
\hline $\begin{array}{l}\text { Q3 } \\
\text { EFFICIENCY } \\
\text { CONCERNS }\end{array}$ & $\begin{array}{l}\text { PERFORMANCE/ } \\
\text { TASK } \\
\text { MANAGEMENT }\end{array}$ & $\begin{array}{l}\text { PRODUCER (E) } \\
\text { MONITOR (I) }\end{array}$ & $\begin{array}{l}\text { Effective use of } \\
\text { ICT to display } \\
\text { share and use } \\
\text { performance } \\
\text { data and act on } \\
\text { the data }\end{array}$ \\
\hline $\begin{array}{l}\text { Q4 } \\
\text { EFFECTIVENESS } \\
\text { CONCERNS }\end{array}$ & $\begin{array}{l}\text { STRATEGIC } \\
\text { MANAGEMENT }\end{array}$ & $\begin{array}{l}\text { DIRECTOR (I) } \\
\text { BROKER (E) }\end{array}$ & $\begin{array}{l}\text { Effective use of } \\
\text { ICT to ensure } \\
\text { vision, goals } \\
\text { and } \\
\text { achievements } \\
\text { are shared and } \\
\text { resources }\end{array}$ \\
\hline
\end{tabular}

(C) 2010 IASL, SLAQ and therein by the authors. Diversity Challenge Resilience: School Libraries in Action Proceedings of the $12^{\text {th }}$ Biennial School Library Association of Queensland, the $39^{\text {th }}$ International Association of School Librarianship Annual Conference incorporating the $14^{\text {th }}$ International Forum on Research in School Librarianship, Brisbane QLD Australia, 27 September - 1 October 2010. 


\begin{tabular}{|l|l|l|}
\hline & & $\begin{array}{l}\text { allocated and } \\
\text { used wisely }\end{array}$ \\
\hline
\end{tabular}

Table 3

Relationship between ICT support and purpose in leadership

\begin{tabular}{|c|c|c|c|}
\hline$\frac{\text { MAIN OUTCOME }}{\frac{\text { (QUADRANT OF }}{\underline{\text { CONCERN })}}}$ & $\frac{\frac{\text { SITUATIONAL }}{\text { LEADERSHIP TYPE }}}{\underline{\text { REQUIRED }}}$ & $\frac{\frac{\text { PURPOSES OF }}{\text { LEADERSHIP }}}{\underline{\text { ROLES }}}$ & $\begin{array}{l}\text { MAJOR USES } \\
\text { OF ICT } \\
\text { (ie Selecting } \\
\text { and Using ICT } \\
\text { to provide or } \\
\text { support:-) }\end{array}$ \\
\hline $\begin{array}{l}\text { Q1 } \\
\text { SPIRIT }\end{array}$ & $\begin{array}{l}\text { VISIONARY } \\
\text { LEADERSHIP }\end{array}$ & $\begin{array}{l}\text { LEADERSHIP } \\
\text { THAT BRINGS } \\
\text { ABOUT A NEW } \\
\text { WAY OF } \\
\text { WORKING }\end{array}$ & $\begin{array}{l}\text { Communicating } \\
\text { best practice, } \\
\text { share 'wins and } \\
\text { losses'; } \\
\text { 'excellent } \\
\text { mistakes' }\end{array}$ \\
\hline $\begin{array}{l}\text { Q2 } \\
\text { PEOPLE WELL } \\
\text { BEING CONCERNS }\end{array}$ & $\begin{array}{l}\text { PEOPLE } \\
\text { LEADERSHIP }\end{array}$ & $\begin{array}{l}\text { MOTIVATE } \\
\text { AND } \\
\text { DEVELOP } \\
\text { PEOPLE }\end{array}$ & $\begin{array}{l}\text { Sharing:- Case } \\
\text { Studies, Stories } \\
\text { Exemplars and } \\
\text { provide praise } \\
\text { and mentoring }\end{array}$ \\
\hline $\begin{array}{l}\text { Q3 } \\
\text { EFFICIENCY } \\
\text { CONCERNS }\end{array}$ & $\begin{array}{l}\text { PERFORMANCE/ } \\
\text { TASK } \\
\text { MANAGEMENT }\end{array}$ & $\begin{array}{l}\text { ENSURE THAT } \\
\text { TASKS GET } \\
\text { DONE ON } \\
\text { TIME. AND } \\
\text { EFFICIENTLY }\end{array}$ & $\begin{array}{l}\text { Measure, report } \\
\text { and act upon } \\
\text { key selected } \\
\text { outcomes and } \\
\text { processes }\end{array}$ \\
\hline $\begin{array}{l}\text { Q4 } \\
\text { EFFECTIVENESS } \\
\text { CONCERNS }\end{array}$ & $\begin{array}{l}\text { STRATEGIC } \\
\text { MANAGEMENT }\end{array}$ & $\begin{array}{l}\text { ACHIEVE THE } \\
\text { IMPORTANT } \\
\text { GOALS }\end{array}$ & $\begin{array}{l}\text { Establishing } \\
\text { Forums, } \\
\text { Reporting Goal } \\
\text { Achievements } \\
\text { and Failures }\end{array}$ \\
\hline
\end{tabular}

Table 4

Some iCentre change entry points

Required leadership outcome and ways of using staff development and ICT based support

The librarian as CIO and the iCentre should 'drive' ICT based systems as follows:

\begin{tabular}{|c|c|c|c|}
\hline $\begin{array}{c}\frac{\underline{\text { MAIN }}}{\text { OUTCOME }} \\
\frac{\text { QUADRANT OF }}{\text { CONCERN) }}\end{array}$ & $\frac{\text { BASIS OF }}{\text { APPROACH }}$ & $\begin{array}{l}\frac{\text { APPROPRIATE }}{\text { STAFF }} \\
\frac{\underline{\text { FOCUS \& }}}{\underline{\text { ACTION }}} \\
\underline{\text { OUTCOMES }}\end{array}$ & $\begin{array}{l}\frac{\text { MAJOR USES OF }}{\text { I.C.T. }} \\
\text { (i.e. Selecting and } \\
\text { Using I.C.T. to:-) }\end{array}$ \\
\hline $\begin{array}{l}\text { QUADRANT } 1 \\
\text { COMMUNITY AND } \\
\text { CULTURE } \\
\text { CONCERNS }\end{array}$ & $\begin{array}{l}\text { SPIRIT } \\
\text { (VALUES) }\end{array}$ & $\begin{array}{l}\text { VISION } \\
\text { INNOVATION } \\
\text { CULTURAL } \\
\text { CHANGE }\end{array}$ & $\begin{array}{l}\text { Provide Inclusive, 24/7 } \\
\text { Ways of Developing, } \\
\text { Disseminating And } \\
\text { Sharing These Ideas } \\
\text { For The School and its } \\
\text { Community }\end{array}$ \\
\hline
\end{tabular}

(C) 2010 IASL, SLAQ and therein by the authors. Diversity Challenge Resilience: School Libraries in Action Proceedings of the $12^{\text {th }}$ Biennial School Library Association of Queensland, the $39^{\text {th }}$ International Association of School Librarianship Annual Conference incorporating the $14^{\text {th }}$ International Forum on Research in School Librarianship, Brisbane QLD Australia, 27 September - 1 October 2010. 


\begin{tabular}{|l|l|l|l|}
\hline $\begin{array}{l}\text { QUADRANT 2 } \\
\text { PEOPLE WELL } \\
\text { BEING CONCERNS }\end{array}$ & $\begin{array}{l}\text { HEART } \\
\text { (FEELINGS) }\end{array}$ & $\begin{array}{l}\text { PEOPLE AND } \\
\text { TEAM SKILLS } \\
\text { LIVE THE VALUES }\end{array}$ & $\begin{array}{l}\text { Facilitate Dialogue; } \\
\text { Share Wins and Losses; } \\
\text { Develop and Practise } \\
\text { Electronic Learning } \\
\text { Communities }\end{array}$ \\
\hline $\begin{array}{l}\text { QUADRANT 3 } \\
\text { EFFICIENCY } \\
\text { CONCERNS }\end{array}$ & $\begin{array}{l}\text { HANDS } \\
\text { (SKILLS) }\end{array}$ & $\begin{array}{l}\text { PERFORMANCE } \\
\text { MANAGEMENT } \\
\text { RESOURCE } \\
\text { MANAGEMENT }\end{array}$ & $\begin{array}{l}\text { Track and share } \\
\text { performance on agreed } \\
\text { learning processes and } \\
\text { outcomes } \\
\text { Create efficient systems } \\
\text { and release humans for } \\
\text { higher order learning } \\
\text { tasks }\end{array}$ \\
\hline $\begin{array}{l}\text { QUADRANT 4 } \\
\text { EFFECTIVENESS } \\
\text { CONCERNS }\end{array}$ & HEAD & $\begin{array}{l}\text { GOVERNANCE } \\
\text { STRATEGIC }\end{array}$ & $\begin{array}{l}\text { Effective ways of } \\
\text { developing and sharing } \\
\text { vision, goals and } \\
\text { objectives in } \text {-learning } \\
\text { communities } \\
\text { Effective systems for } \\
\text { supporting the business } \\
\text { of learning }\end{array}$ \\
\hline
\end{tabular}

Clearly, there is a vast agenda of change and action if these types of recommendations are to be implemented, as lmove more to the CIO role and encourage the development of the iCentre concept. The final section of advice is aimed at providing a methodology for selecting which actions should be implemented early, and which actions can reasonably be left to later or not implemented at all

\section{Risk management applied to training}

An important issue facing all educators and especially now is the answer(s) to the questions, What aspects of curriculum should be selected to be taught? To what degree should we invest resources in achieving it being learned? To what degree should we test that learning has actually occurred? These questions are educational versions of risk management thinking, and a very useful resource is Horton (2006) who developed a risk management applied to training methodology, which can be adapted to the tasks of selecting a professional development approach for iCentre priorities.

In essence the approach requires considered answers to the following key questions:-

What item(s) must be taught?

What level(s) of achievement is acceptable?

Have we minimised risk in selecting answers to the above key questions?

The basic risk management matrix is a simple two-way analysis table-which enables level of risk to be matched against level of consequence. The extremes of a simple risk management matrix then become:-

- High Risk + High Consequence

- High Risk + Low Consequence

- Low Risk + High Consequence

- Low Risk + Low Consequence.

This simple but powerful matching approach can be developed into a wide range of more sophisticated analyses.

A typical example becoming familiar to many teachers is now provided of a risk management matrix, which shows likelihood of event matched against possible injury level outcome.

(C) 2010 IASL, SLAQ and therein by the authors. Diversity Challenge Resilience: School Libraries in Action Proceedings of the $12^{\text {th }}$ Biennial School Library Association of Queensland, the $39^{\text {th }}$ International Association of School Librarianship Annual Conference incorporating the $14^{\text {th }}$ International Forum on Research in School Librarianship, Brisbane QLD Australia, 27 September - 1 October 2010. 


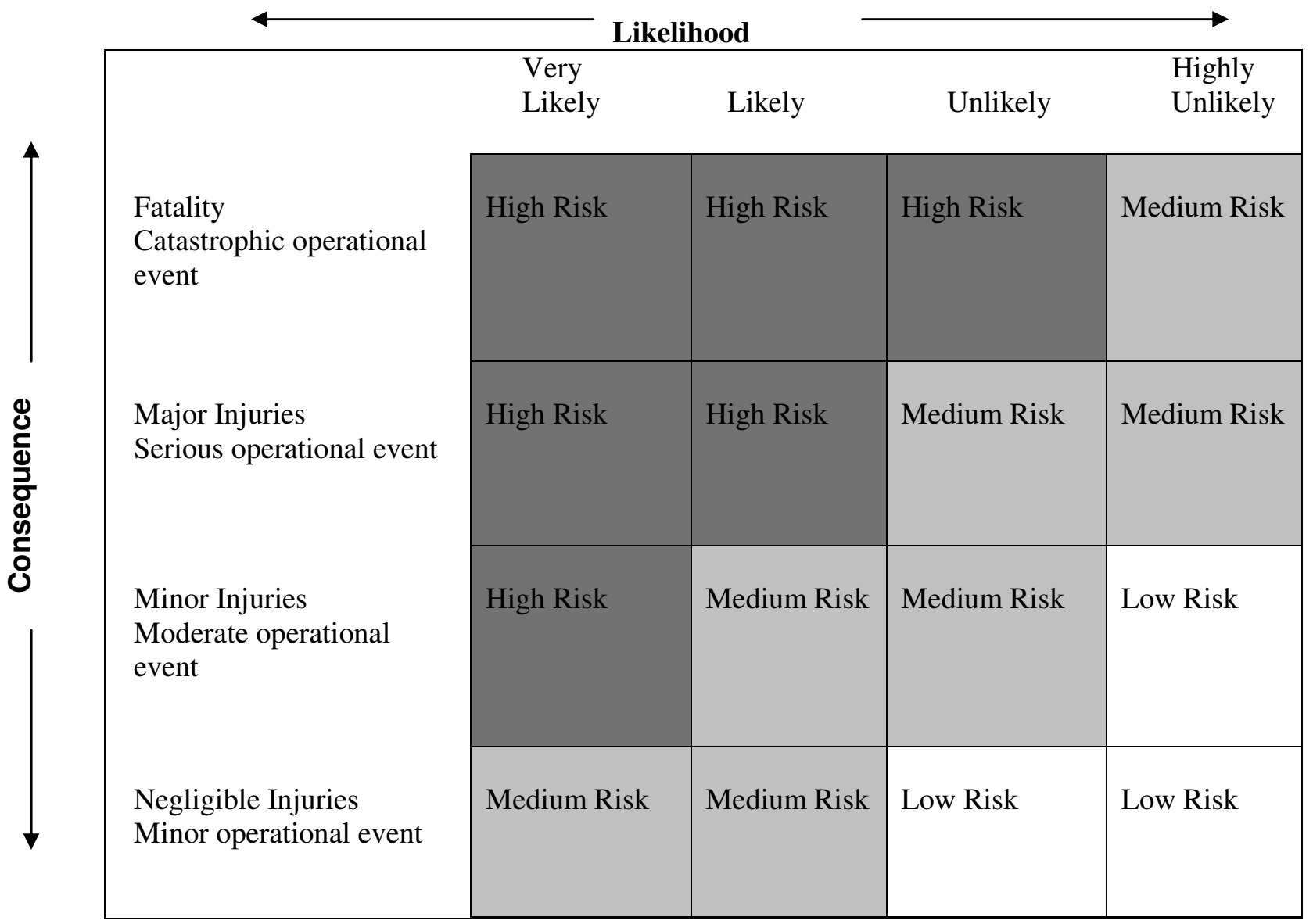

Figure 1 Standard Risk Assessment Matrix (from Horton (2006, 3)

This basic risk management logic - that an analysis of type and level of risk should be a logical basis for making decisions - has been developed and extended into educational applications by the Horton approach. The accompanying presentation will provide more examples of training matrix models, and these training related matrices illustrate ways of making rational decisions about the following staff development issues:

- How relatively important are the education outcomes to be achieved?

- What level of training approach is needed to ensure a desired educational outcome?

- What level of assessment is needed to ensure a desired educational outcome?

- What level of risk is acceptable in achieving a particular outcome?

- How can training decisions be justified and defended?

As will be illustrated by the presentation, a risk matrix based decision needs to be made about the following basic questions:

What items must be selected for achievement?

What level of achievement is acceptable for each item selected?

What training method should be adopted for achieving each selected item to the appropriate level?

What type of assessment should be applied to ensure that the selected item has been effectively achieved?

Once this approach has been successfully adopted, some of the benefits of a risk management approach to training are as follows:

- Improved cost effectiveness of training

- Improved allocation of training resources

- Optimising of training efforts towards important and relevant outcomes

(C) 2010 IASL, SLAQ and therein by the authors. Diversity Challenge Resilience: School Libraries in Action Proceedings of the $12^{\text {th }}$ Biennial School Library Association of Queensland, the $39^{\text {th }}$ International Association of School Librarianship Annual Conference incorporating the $14^{\text {th }}$ International Forum on Research in School Librarianship, Brisbane QLD Australia, 27 September - 1 October 2010. 
- Ensuring appropriate knowledge is included in training

- Ability to demonstrate to internal and external stakeholders fair and equitable training decisions

- Minimisation of organisational legal risks - especially in relation to any statutory training requirements

- Ensuring staff Occupational Health and Safety risks are minimised

\section{Project management of knowledge: The library as a knowledge resource}

Project and/or Risk Management (P.M. and R.M.) can be viewed too narrowly as specific 'tools' to do specific tasks or reactively meet specific needs. They are usually introduced into organisational practice from this perspective, i.e. a need to manage a large complex task, or a need to protect the organisation against legal liability.

These are perfectly valid reasons to introduce these concepts, but what needs to be developed by libraries functioning as iCentres is a far more fundamental capability based on these understandings. It is 'mindsets' such as P.M. and R.M. as two sets of powerful intellectual tools that can build the capability of an organisation and add value to it by capturing, protecting and building upon the knowledge base of the organisation. The library can become the repository and means of accessing both 'past practices' and 'best practices' in aspects of training, eLearning and culture. 'The way we do things around here' can be enhanced by the digital capabilities of an iCentre enabling 24/7 access to basic information, case studies, exemplars, ceremonies and celebrations.

The details contained within these basic approaches outlined above can become quite complex, but the basic risk management principles to be applied are sound and robust. By adopting this approach to deciding priorities of staff development, iCentres can become 'value adding' as well as 'supporting' by becoming valued resource managers and advisers, as well as the best physical and electronic places for the training and learning to occur.

Ways of supporting from an iCentre

The key iCentre related roles -

The librarian as chief information officer (CIO)

Lee (2010) suggests the CIO should provide leadership to ensure that the following requirements can be met:

- High levels of availability of digital technology across school functions

- Adequate deployment of the technology into classrooms

- Actual usage of the technology by teachers and students in classrooms

- Access to online learning platforms (see Becta for example)

- The conditions for normalised teacher and student usage are met (see Lee, 2010, 44)

- Teacher training and support - especially ease of usage in the 'normal' teaching classroom

- Relevance and availability of the technology for example the success and take-up of use the Interactive Whiteboard (IWB)

- Infrastructure

- Finance -see Lee (2010) for a compelling argument that the home is the much greater investment point for student accessible ICT capability, and schools should accept this and learn how to network with these capabilities as a 'normal' relationship

- Leadership

- Implementation

- Bureaucratic and hierarchical control

- Administration and communication -especially level of compatability with eLearning systems

- Impact of the major technology corporations (e.g. Dell, Apple, Microsoft)

The library as an IT support centre

Benefits for teachers

(C) 2010 IASL, SLAQ and therein by the authors. Diversity Challenge Resilience: School Libraries in Action Proceedings of the $12^{\text {th }}$ Biennial School Library Association of Queensland, the $39^{\text {th }}$ International Association of School Librarianship Annual Conference incorporating the $14^{\text {th }}$ International Forum on Research in School Librarianship, Brisbane QLD Australia, 27 September - 1 October 2010. 
Lee $(2010$, Ch 6, 99) quotes a Becta UK (2008) report that found that the strongest general impact of technology was the saving of time, and that up approx $60 \%$ of teachers reported time savings of up to $2 \mathrm{hrs}$ per week.

The reality for students

Lee (2010, Ch 6 factors that strongly favour the home as the major influence on student ICT access and behaviours due to:

- Home gives priority to investing in ICT

- Home can acquire whatever technology it decides

- Parents and young people make rapid and extensive use of digital equipment

- Home provides unlimited and largely free usage for students

- Responsibility for supervising a 'relative few' at home

- Ever increasing resources with little controls

Lee $(2010,40)$ identified the core staff tools as

- An appropriate desktop/laptop/ netbook with wireless capability and required software

- A work email address

- An appropriate work related internet usage service or allocation

The library as a staff development centre

Finger \&Jamieson-Proctor (2010) provide a detailed analysis of teacher readiness issues, recommend the TPACK (Technological Pedagogical Content Knowledge) approach and analyse how working conditions will need to be redesigned.

\section{Concluding comments}

Librarians and school iCentres need to develop and adapt their own versions of the following key action guidelines for successful schooling and learning as follows:

- staff are the key to a successful school and developing their (positive) attitudes to ICT will be a key success factor,

- many of the educational practices with which many current teachers and schools are skilled in are non ICT based, and were derived to meet the needs of a previous society, and are needed less and less by current and future societies,

traditional or 'older' methods of leadership are less and less effective with younger generations and in meeting the needs of a post industrial society,

- ICT based learning will initially be based on existing practices but over time will create interest and capabilities to move to new ways of working in schools,

- younger generations are extremely comfortable and confident with ICT based learning, and will welcome its greater usage in schools and learning,

- technology in itself is not the primary issue - the leadership criterion applied to selecting and using technology should be: does it add value to the key processes and outcomes we have selected as important for the success of this school? and,

- effective schools that maximise student learning are those schools that focus on making their staff as professional and confident as possible in the value adding usage of ICT (These guidelines adapted from Hough, 2009, 259-260).

\section{Three action recommendations:}

- School librarians and school iCentres need to become central agencies in the staff development upgrades of staff, students and parents as the networked learning community emerges.

(C) 2010 IASL, SLAQ and therein by the authors. Diversity Challenge Resilience: School Libraries in Action Proceedings of the $12^{\text {th }}$ Biennial School Library Association of Queensland, the $39^{\text {th }}$ International Association of School Librarianship Annual Conference incorporating the $14^{\text {th }}$ International Forum on Research in School Librarianship, Brisbane QLD Australia, 27 September - 1 October 2010. 
- iCentres should promote adaptive staff development which must be developed using 'targeting' techniques such as risk management applied to staff development choices, if the wide range of challenges and needs is to be met in upgrading teachers and leaders in our schools.

- Librarians need to exert a leadership role in the ICT support of teachers and leaders by developing into the chief information officer $(\mathrm{CIO})$ role. A role which will require them to remain current in the developing technologies and recommended options, to provide effective leadership in selecting wisely from ICT options and usages, and be available to 'project manage' and 'house' the actual approaches developed.

\section{A PRACTICAL APPROACH :- KEEP, CHANGE, TRY}

At many points across the morning's presentations, you will be asked to reflect, discuss and consider an initial set of action possibilities for different action research projects you could work on to implement the changes required to move towards more effective relationships between generations at work

Please try the following logic framework on organising your reactions and discussions on these ideas and suggestions:

What are:

The Key Things (actual practices) that Your Library / School should KEEP to Improve Its' Capabilities?

The Key Things (actual practices) that Your Library / School should CHANGE to Improve Its' Capabilities?

The Key Things That Your Library / School Should TRY to Improve Its' Capabilities?

SOME ACTION FOCUS POINTS:-

\begin{tabular}{|c|c|c|c|c|}
\hline $\begin{array}{c}\text { INDIVIDUAL } \\
\text { EMPLOYEE } \\
\text { LEVEL }\end{array}$ & $\begin{array}{c}\text { WORK } \\
\text { GROUP } \\
\text { LEVEL }\end{array}$ & $\begin{array}{c}\text { DIVISION OR } \\
\text { UNIT } \\
\text { LEVEL }\end{array}$ & $\begin{array}{c}\text { WHOLE } \\
\text { ORGANIZATION } \\
\text { LEVEL }\end{array}$ & $\begin{array}{c}\text { COMMUNITY } \\
\text { LEVEL }\end{array}$ \\
\hline & & & & \\
\hline & & & & \\
\hline & & & & \\
\hline & & & & \\
\hline
\end{tabular}

OTHER USEFUL IDEAS FOR FURTHER EXPLORATION

\section{Bibliography}

Buchel, K. (2009). The Ten Commandments of Generation Z. Retrieved from http://www1.auspost.com.au/priority/index.asp?area=features\&article_id=966\&issue_id=46

Caldwell, B., Spinks, J. (2008). Still raising the stakes. The Australian Educational Leader 30 (1), 6-10.

SMH 14 May (2007). Corporate responsibility index CRI: Special report. Sydney Morning Herald Supplement.

(C) 2010 IASL, SLAQ and therein by the authors. Diversity Challenge Resilience: School Libraries in Action Proceedings of the $12^{\text {th }}$ Biennial School Library Association of Queensland, the $39^{\text {th }}$ International Association of School Librarianship Annual Conference incorporating the $14^{\text {th }}$ International Forum on Research in School Librarianship, Brisbane QLD Australia, 27 September - 1 October 2010. 
Cranston, N. \& Ehrich, L. (2009) Australian school leadership today. Bowen Hill QLD. Australian Academic Press

Finger, G. \& Jamieson-Proctor, R. Teacher readiness: TPACK capabilities and redesigning working conditions. In Lee, M. \& Finger, G. (Eds). (2010). Developing a networked school community: A guide to realising the vision. Camberwell, VIC. ACER.

Gettier, L. (2008). Stand out from the crowd, Sydney Morning Herald, 2007 Corporate Responsibility Index Report, Sydney, 20 May 2008.

Hay, L. Developing an information paradigm approach to build and support the home-school. In Lee, M. \& Finger, G. (Eds). (2010). Developing a networked school community: A guide to realising the vision. Camberwell, VIC. ACER.

Hough, M. (2006). Using project and risk management to add capability to your organisation. Papers presented to Inaugural Asia-Pacific Value Convention Hong Kong.

Hough, M. (2008a). Successful learning and school design for the knowledge age. In Lee, M. \& Gaffney, M. (Eds) (2008). Leading a digital school. Camberwell, VIC. ACER.

Hough, M. (2008b) What went wrong? Chartered Secretaries Journal Greed is good? Rethinking corporate values Hong Kong. ICS. Nov 2008, 12-15.

Hough, M. (2009). Technology and the principal: Implications for leadership. In Cranston, N. \& Ehrich, L. (2009). Australian school leadership today. Bowen Hill QLD. Australian Academic Press.

IBM (2010) Midsize businesses are the engines of a smarter planet. In Management Today June 2010, 7.

Lee M. and Gaffney M. (Eds) (2008). Leading a digital school. Camberwell, VIC. ACER.

Lee, M. \& Finger, G. (Eds). (2010). Developing a networked school community: A guide to realising the vision. Camberwell, VIC. ACER.

Lee, M. \& Finger, G. (2010). The challenge: Developing a networked model of schooling. In Lee, M. \& Finger, G. (Eds). (2010). Developing a networked school community: A guide to realising the vision. Camberwell, VIC. ACER.

Lee, M (2010a). The networked school community today. In Lee, M. \& Finger, G. (Eds). (2010). Developing a networked school community: A guide to realising the vision. Camberwell, VIC. ACER.

Lee, M. (2010b). Schools and digital technology: An overview. In: Lee, M. \& Finger, G. (Eds). (2010). Developing a networked school community: A guide to realising the vision. Camberwell, VIC. ACER.

Lee. M. (2010c). The rationale. In Lee, M. \& Finger, G. (Eds). (2010). Developing a networked school community: A guide to realising the vision. Camberwell, VIC. ACER.

Lee, M. \& Levins, M, Homes and the digital technology: A home-school difference or a digital divide? In Lee, M. \& Finger, G. (Eds). (2010). Developing a networked school community: A guide to realising the vision. Camberwell, VIC. ACER.

Lee, M. \& Ryall, B. Financing the networked community: Building on the home investment. In Lee, M. \& Finger, G. (Eds). (2010). Developing a networked school community: A guide to realising the vision. Camberwell, VIC. ACER.

(C) 2010 IASL, SLAQ and therein by the authors. Diversity Challenge Resilience: School Libraries in Action Proceedings of the $12^{\text {th }}$ Biennial School Library Association of Queensland, the $39^{\text {th }}$ International Association of School Librarianship Annual Conference incorporating the $14^{\text {th }}$ International Forum on Research in School Librarianship, Brisbane QLD Australia, 27 September - 1 October 2010. 
Lennick, D., Kiel, F. (2005). Moral intelligence: Enhancing business performance and leadership success Wharton.

Maher, D. \& Lee, M. (2010). Student Internet usage in a networked school community: The challenge. In Lee, M. \& Finger, G. (Eds). (2010). Developing a networked school community: A guide to realising the vision. Camberwell, VIC. ACER.

Murdoch, R. (2008). New forces from this maelstrom: $2^{\text {nd }}$ Lecture in Boyer Series, The Golden Age of Freedom,_Australian Broadcasting Corporation see www.abc.net.au/m/boyerlectures, as reported in Weekend Australian Inquirer 8-9 Nov. 2008.

Prensky, M. (2005) Listen to the natives. Educational Leadership, 63-4, 8-13.

Shapiro, R. (2008). FutureCast 2020: A global vision of tomorrow. London UK: Profile Books.

Twyford, V et al (2007). Beyond public meetings: Connecting community engagement with decision making, University of New South Wales UNSW (2008) Engineering Modelling The Future:- Engineering For Clever Outcomes 17, June 2008, 8-14

Useful websites

The following are useful websites for researching culture related aspects:-

www.ita.doc.gov

www.culturegrams.com

www.runzheimer.com

www.hsbc.com

www.worldtrademag.com

The following website is for the Australian Corporate Responsibility Index

www.corporate_responsibility.com.au

The following websites are for Business Excellence Awards:-

www.baldrige.org

www.businessexcellenceaustralia.com.au

The Gates Foundation:- www.gatesfoundation.org/StoryGallery/

Some exemplar websites

http://fish4info.org/ is an example of a next generation school library catalogue (Ref:- Hay 2010, 153)

(C) 2010 IASL, SLAQ and therein by the authors. Diversity Challenge Resilience: School Libraries in Action Proceedings of the $12^{\text {th }}$ Biennial School Library Association of Queensland, the $39^{\text {th }}$ International Association of School Librarianship Annual Conference incorporating the $14^{\text {th }}$ International Forum on Research in School Librarianship, Brisbane QLD Australia, 27 September - 1 October 2010. 